\title{
COSMOS: cloud enabled NGS analysis
}

\author{
Yassine Souilmi ${ }^{1,2}$, Jae-Yoon Jung ${ }^{2}$, Alex Lancaster ${ }^{2}$, Erik Gafni ${ }^{3}$, Saaid Amzazi ${ }^{1}$, Hassan Ghazall ${ }^{4}$ Dennis Wall ${ }^{2,5}$, \\ Peter Tonellato ${ }^{2^{*}}$
}

From Tenth International Society for Computational Biology (ISCB) Student Council Symposium 2014 Boston, MA, USA. 11 July 2014

\section{Background}

The dramatic fall of next generation sequencing (NGS) cost in recent years positions the price in range of typical medical testing, and thus whole genome analysis (WGA) may be a viable clinical diagnostic tool. Modern sequencing platforms routinely generate petabyte data. The current challenge lies in calling and analyzing this large-scale data, which has become the new time and cost rate-limiting step.

\section{Methods}

To address the computational limitations and optimize the cost, we have developed COSMOS (http://cosmos.hms. harvard.edu), a scalable, parallelizable workflow management system running on clouds (e.g., Amazon Web Services or Google Clouds). Using COSMOS [1], we have constructed a NGS analysis pipeline implementing the Genome Analysis Toolkit - GATK v3.1 - best practice protocol $[2,3]$, a widely accepted industry standard developed by the Broad Institute. COSMOS performs a thorough sequence analysis, including quality control, alignment, variant calling and an unprecedented level of annotation using a custom extension of ANNOVAR. COSMOS takes advantage of parallelization and the resources of a highperformance compute cluster, either local or in the cloud, to process datasets of up to the petabyte scale, which is becoming standard in NGS.

\section{Conclusion}

This approach enables the timely and cost-effective implementation of NGS analysis, allowing for it to be used in a clinical setting and translational medicine. With COSMOS we reduced the whole genome data analysis cost under the $\$ 100$ barrier, placing it within a reimbursable cost point and in clinical time, providing a significant change

${ }^{2}$ Center for Biomedical Informatics, Harvard Medical School, Boston, MA 02115, USA

Full list of author information is available at the end of the article to the landscape of genomic analysis and cement the utility of cloud environment as a resource for Petabyte-scale genomic research.

\section{Authors' details}

${ }^{1}$ Department of Biology, Faculty of Sciences of Rabat, Morocco. ${ }^{2}$ Center for Biomedical Informatics, Harvard Medical School, Boston, MA 02115, USA. ${ }^{3}$ INVITAE, San Francisco, CA 94107, USA. ${ }^{4}$ Department of Biology, Mohamed First University, Oujda/Nador, Morocco. ${ }^{5}$ Department of Pediatrics, Division of Systems Medicine, Stanford University, Stanford, CA 94305, USA.

Published: 28 January 2015

\section{References}

1. Gafni E, Luquette $L$, Lancaster AK, Hawkins JB, Jung J-Y, Souilmi Y, Wall DP, Tonellato PJ: COSMOS: Python library for massively parallel workflows. Bioinformatics 2014, btu385.

2. DePristo MA, Banks E, Poplin R, Garimella KV, Maguire JR, Hartl C, Philippakis AA, del Angel G, Rivas MA, Hanna M, McKenna A, Fennell TJ, Kernytsky AM, Sivachenko AY, Cibulskis K, Gabriel SB, Altshuler D, Daly MJ: A framework for variation discovery and genotyping using nextgeneration DNA sequencing data. Nat Genet 2011, 43:491-498.

3. Van der Auwera GA, Carneiro MO, Hartl C, Poplin R, del Angel G, LevyMoonshine A, Jordan T, Shakir K, Roazen D, Thibault J, Banks E, Garimella KV, Altshuler D, Gabriel S, DePristo MA: From FastQ Data to High-Confidence Variant Calls: The Genome Analysis Toolkit Best Practices Pipeline. 2013.

doi:10.1186/1471-2105-16-S2-A2

Cite this article as: Souilmi et al:: COSMOS: cloud enabled NGS analysis. BMC Bioinformatics 2015 16(Suppl 2):A2.

\section{Submit your next manuscript to BioMed Central} and take full advantage of:

- Convenient online submission

- Thorough peer review

- No space constraints or color figure charges

- Immediate publication on acceptance

- Inclusion in PubMed, CAS, Scopus and Google Scholar

- Research which is freely available for redistribution
() Biomed Central

(c) 2015 Souilmi et al; licensee BioMed Central Ltd. This is an Open Access article distributed under the terms of the Creative Commons Attribution License (http://creativecommons.org/licenses/by/4.0), which permits unrestricted use, distribution, and reproduction in any medium, provided the original work is properly cited. The Creative Commons Public Domain Dedication waiver (http:// creativecommons.org/publicdomain/zero/1.0/) applies to the data made available in this article, unless otherwise stated. 